\title{
Teologia da Criança: a infância como caminho de se falar sobre Deus, a vida cristã e os vulneráveis
}

\author{
Orientadora: Maria Clara Lucchetti Bingemer \\ Mestrando: Benjamim Sathler Lenz Cesar \\ Área de Concentração: Teologia Sistemático-Pastoral \\ Linha de Pesquisa: Religião e Modernidade
}

A Teologia da Criança é o campo de pesquisa que tem como sujeito teológico o ser humano de pouca idade e denuncia o adultocentrismo como estrutura de opressão. $\mathrm{O}$ centro de toda construção teológica se estabelece ao redor e a partir da figura da criança. A pesquisa tem como objetivo analisar a relação entre a experiência de Deus e a valorização da infância, sinalizando a existência de uma ligação estreita entre um e outro. A experiência com o Mistério ganha novos contornos a partir da mística singular das crianças, bem como a infância adquire novas cores a partir da revelação desse Mistério em Jesus Cristo. Os pequeninos são a parábola que as Escrituras utilizam para falar sobre Deus, a vida cristã e os vulneráveis desse mundo, transcendendo assim a razão, a instituição e o consumo como lógica adultocentrica e propondo a mística, a liberdade e a generosidade como alternativa para se fazer como criança. Os adultos podem e devem reconhecer nas crianças um caminho para a experiência real de Deus.

Palavras-chave: Teologia. Criança. Infância. 